Goldschmidt 2021 Abstract

https://doi.org/10.7185/gold2021.8186

\title{
Observing the plutonic-volcanic connection
}

\section{JOAN MARTÍ}

\section{Geosciences Barcelona, CSIC}

Presenting Author: jmarti@geo3bcn.csic.es

The volcanic-plutonic connection has been postulated mostly based on indirect evidence coming from geochemical, petrological, and geophysical approaches, and theoretical modelling. However, very few direct field examples of such connection have been offered. The reason is that most well exposed volcanic terrains are so young for erosion or tectonics to have exhumed their deeper plutonic roots, while plutonic terrains are too old to preserve possible coeval volcanic equivalents. The Pyrenees, an Alpine mountain range located between Spain and France, offers an exception to this general rule, and exposes cogenetic and coeval plutonic, subvolcanic and volcanic rocks that offer good field evidence of the existence of such plutonicvolcanic connection. A significant portion of the continental crust ranging in age from the Cambro-Ordovician to Permian, exposes two examples of such connection corresponding to the upper Ordovician and the Upper Carboniferous-Lower Permian magmatic episodes. In both cases, volcanic rocks are the eruptive expression of these magmatic episodes, which also generated large plutonic bodies and subvolcanic dyke complexes emplaced at very sallow depths. The field-based stratigraphic and structural reconstruction of some of these plutonic-subvolcanic-volcanic complexes, as well as new zircon U-Th radiometric ages and petrological and geochemical data, demonstrate that there was a time-space and genetic relationship between them, thus offering one of the scarce direct evidence of the existence of the so many times postulated but still not clearly proved plutonic-volcanic connection.

This research is supported by MINECO grant SIMPROP (CGL2017-84901-C2) 